\title{
AKTIVITAS ANTIHIPERKOLESTEROLEMIA EKSTRAK AKAR DAN BATANG KEMANGI HUTAN (Ocimum sanctum) PADA TIKUS PUTIH
}

\author{
Yohana K. A. Mbulang ${ }^{1}$, Agustine E. Amsikan ${ }^{2}$, Aloysius M. Kopon ${ }^{3}$ \\ ${ }^{1)}$ Program Studi Farmasi Universitas Citra Bangsa Kupang \\ ${ }^{2)}$ Program Studi Sarjana Farmasi Universitas Citra Bangsa Kupang \\ ${ }^{3)}$ Program Studi Farmasi Universitas Citra Bangsa Kupang \\ Email : ayepa92@gmail.com
}

\begin{abstract}
Hypercholesterolemia is a high level of cholesterol in the blood $\geq 200 \mathrm{mg} / \mathrm{dl}$. Ocimum sanctum is medical plants which have antihypercholesterolemic effects. This study aims to determine that antihypercholesterolemic activity and the best dose of roots and stems extracts of Ocimum sanctum which can provide antihypercholesterolemic effects in white rats fed a high fat diet. A total of 25 rats divided into 5 groups that is group positive control, group negative control, group roots and stems extracts of Ocimum sanctum with dose of $50 \mathrm{mg} / \mathrm{kg}$ body weight, $75 \mathrm{mg} / \mathrm{kg}$ body weight and $100 \mathrm{mg} / \mathrm{kg}$ body weight. Cholesterol and triglyseride levels measurement using the CHOP- PAP and GPO-PAP methods. The results of statistical analysis showed that there was an antihypercholesterolemic effect from the three doses of root and stem extracts Ocimum sanctum. The best dose as an antihypercholesterolemia is dose III (100 mg/kg body weight).
\end{abstract}

Keywords : Antihypercholesterol, total cholesterol, triglycerides.

\begin{abstract}
ABSTRAK
Hiperkolesterolemia merupakan tingginya kadar total kolesterol dalam darah $\geq 200 \mathrm{mg} / \mathrm{dl}$. Kemangi hutan merupakan tanaman obat yang memiliki efek sebagai antihiperkolesterolemia. Penelitian ini bertujuan untuk mengetahui aktivitas antihiperkolesterolemia dan dosis yang paling baik dari ekstrak akar dan batang kemangi hutan yang dapat memberikan efek antihiperkolesterolemia pada tikus putih yang diberi pakan diet lemak tinggi. Sebanyak 25 ekor tikus dibagi 5 kelompok yaitu kelompok kontrol positif, kelompok kontrol negatif, kelompok ekstrak akar dan batang kemangi hutan dengan dosis $50 \mathrm{mg} / \mathrm{kg} \mathrm{BB}, 75 \mathrm{mg} / \mathrm{kg} \mathrm{BB}$, dan $100 \mathrm{mg} / \mathrm{kg}$ BB. Kadar kolesterol dan trigliserida diukur menggunakan metode CHOD-PAP dan GPO-PAP. Hasil analisis statistik menunjukkan adanya efek antihiperkolesterolemia dari ketiga dosis ekstrak akar dan batang kemangi hutan. Dosis yang paling baik sebagai antihiperkolesterolemia adalah dosis III (100 mg/kg BB).
\end{abstract}

Kata kunci : Antihiperkolesterolemia, kolesterol total, trigliserida.

\section{PENDAHULUAN}

Hiperkolesterolemia merupakan tingginya kadar total kolesterol dalam darah $\geq 200 \mathrm{mg} / \mathrm{dl}$ (Lestari Widya, 2017). Hiperkolesterolemia dapat terjadi karena gaya hidup yang tidak sehat, seperti mengkonsumsi makanan yang tidak seimbang dan kurangnya aktivitas olahraga. Tingginya kadar kolesterol dapat disebabkan oleh sintesis kolesterol dan penyerapan kolesterol yang tinggi dan juga karena kebiasaan konsumsi makanan tinggi lemak serta tinggi karbohidrat (Hernawati dkk., 2013). Kolesterol berlebihan dalam darah dapat membentuk plak pada dinding pembuluh darah yang dapat menyebabkan penyempitan lumen yang dinamakan aterosklerosis (Susiwati dkk., 2018). Konsumsi lemak $100 \mathrm{mg} /$ hari dapat 
meningkatkan kolesterol total sebanyak 2-3 mg/dl (Yani, 2015).

Prevalensi hiperkolesterolemia di Indonesia pada kelompok usia 25-34 tahun adalah 9,3\% dan meningkat sesuai dengan pertambahan usia pada kelompok usia 55-64 hingga 15,5\% (Aurora dkk., 2012). Profil Penyakit Tidak Menular (PTM) tahun 2016 pada Puskesmas di Provinsi NTT berada pada urutan ke-16 dari 34 Provinsi dengan \% kolesterol tinggi yaitu 43,8\% (Kemenkes RI, 2017).

Upaya pencegahan penyakit hiperkolesterolemia dapat dilakukan dengan berbagai cara seperti perubahan gaya hidup yaitu dengan mengkonsumsi jenis sayur dan buah yang mengandung tinggi serat dan antioksidan, juga dengan penggunaan obat antilipemika. Obat yang paling sering digunakan adalah simvastatin. Simvastatin dapat memberikan efek samping seperti rambut rontok (reversible), gangguan psikis (depresi, ketakutan, kecendrungan bunuh diri) dan kerusakan hati (hepatitis) (Tjay dan Rahardja, 2015).

Karena efek samping dari obat-obat antilipemika maka diperlukan alternatif lain untuk mengurangi efek samping yang terjadi dengan penggunaan obat herbal. Penggunaan tumbuhan sebagai obat herbal merupakan pendekatan yang populer untuk perawatan kesehatan, dan juga merupakan suatu cara pengobatan di berbagai daerah berkembang (Hermin dkk, 2016). Salah satu tanaman yang memiliki aktivitas sebagai antihiperkolesterolemia adalah kemangi hutan (Ocimum sanctum). Kandungan kelompok senyawa kimia dalam tanaman kemangi hutan yang diduga memiliki peran dalam aktivitas penurunan kolesterol adalah flavanoid, tanin dan eugenol.

Hasil penelitian Samak et al. (2007) menunjukkan bahwa ekstrak daun kemangi hutan (Ocimum sanctum) dengan dosis 25, atau $50 \mathrm{mg} / \mathrm{kg}$ berat badan dapat menurunkan LDLKolesterol, kolesterol dan trigliserida di hati dan aorta pada kelinci albino jantan yang diberi kolesterol 0,5 g/hari selama 45 hari. Hasil penelitian lainnya oleh Rachmawati et al. (2019) menyatakan bahwa ekstrak daun kemangi dengan dosis $80 \mathrm{mg} / \mathrm{kgBB}$ yang dapat menurunkan kadar kolesterol yang signifikan. Penelitian ini akan menggunakan bagian tanaman yang berbeda dari penelitian sebelumnya yaitu akar dan batang dari tanaman kemangi hutan.

\section{METODE PENELITIAN}

\section{a. Tempat dan Waktu Penelitian}

Penelitian ini dilaksanakan di Laboratorium Farmasi Universitas Citra Bangsa pada bulan Juli-September 2020.

\section{b. Bahan}

Bahan yang digunakan adalah akar dan batang kemangi hutan, Etanol $70 \%$, air, aquadest, pereaksi Wagner, pereaksi Mayer, larutan $\mathrm{HCL} 1 \%$, larutan $\mathrm{HCl}$ pekat, $\mathrm{FeCl}_{3}$, pita $\mathrm{Mg}$, larutan $\mathrm{H}_{2} \mathrm{SO}_{4}$, asam asetat glasial, kloroform, reagen kolesterol, simvastatin sebagai kontrol positif, $\mathrm{Na}$ CMC 0,5\% sebagai kontrol negatif, pakan diet lemak tinggi yaitu kuning telur puyuh, dan pakan standar.

\section{c. Prosedur Penelitian}

\section{Pembuatan Ekstrak Akar dan Batang Kemangi Hutan}

Serbuk akar dan batang kemangi hutan, ditimbang masing-masing sebanyak $500 \mathrm{~g}$ dan dimasukan ke dalam botol kaca cokelat. Kemudian ditambahkan etanol $70 \%$ sebanyak 2500 $\mathrm{mL}$ sampai menutupi seluruh bagian serbuk simplisia dan campuran dikocok hingga tercmpur merata. Ekstrak disimpan selama 3 hari terhindar dari cahaya matahari dan diletakan pada suhu ruangan serta sesekali digojok. Rendaman simplisia disaring menggunakan corong dan kertas saring. Filtrat yang didapat didiamkan selama 2 hari untuk mengurangi kadar alkohol, kemudian 
diuapkan menggunakan evaporator pada suhu $40^{\circ} \mathrm{C}$, untuk mendapatkan ekstrak kental. Selanjutnya dihitung persentase rendemen ekstrak dengan menggunakan rumus:

$\%$ Rendemen Ekstrak $=$

$\frac{\text { Berat ekstrak }(g)}{\text { Berat simplisia kering }(g)} \times 100$

\section{Uji Residu Pelarut Ekstrak Etanol}

Uji residu pelarut dilakukan dengan 2 metode yaitu reaksi esterifikasi dan menggunakan alkoholmeter.

\subsection{Reaksi esterifikasi}

Sebanyak $4 \mathrm{~mL}$ minyak goreng dimasukkan ke dalam kaca arloji, kemudian ditambahkan ekstrak akar dan batang kemangi hutan sebanyak 0,01 mg dan asam sulfat $98 \%$ sebanyak 3 tetes lalu membaui aroma yang dihasilkan. Jika tercium aroma wangi maka ekstrak tersebut masih mengandung pelarut etanol, jika tidak tercium aroma harum maka ekstrak tidak mengandung etanol dan merupakan ekstrak murni.

\subsection{Alkoholmeter}

Ekstrak akar dan batang kemangi hutan dilarutkan dengan aquadest dalam gelas ukur, kemudian masukan alkoholmeter ke dalam gelas ukur tersebut, alkoholmeter dibiarkan mengapung dan amati angka pada alat alkoholmeter.

\section{Uji Sifat Fisikokimia}

\subsection{Massa Jenis}

Gelas kimia $10 \mathrm{~mL}$ ditimbang, dipanaskan pada suhu $110{ }^{0} \mathrm{C}$ selama 15 menit dan didinginkan dalam desikator. Timbang kembali beaker gelas tersebut (perlakuan dilakukan secara berulang sampai mendapat berat gelas kimia yang konstan).

Masukkan ekstrak akar dan batang kemangi hutan sebanyak $1 \mathrm{mg}$ ke dalam gelas kimia tersebut, tambahkan etanol 95\% sebanyak $1 \mathrm{~mL}$, aduk sampai homogen, timbang volume larutan kombinasi ekstrak akar dan batang kemangi hutan dah hitung massa jenisnya dengan rumus :

\subsection{Kelarutan}

$$
\rho=\frac{\text { massa ekstrak }}{\text { volume ekstrak }}
$$

Masukkan ekstrak akar dan batang kemangi hutan sebanyak 0,01 $\mathrm{mg}$ tambahkan $2 \mathrm{~mL}$ aquadest, kocok campuran dan amati kelarutan yang terjadi. Ulangi langkah tersebut dengan menggantikan aquadest dengan etanol 95\% pa, aseton $98 \%$ pa, dan kloroform $95 \%$ pa.

\subsection{Titik Didih}

Masukkan ekstrak akar dan batang kemangi hutan sebanyak $0,1 \mathrm{mg}$ ke dalam cawan petri yang telah dilengkapi dengan termometer pada statif, dipanaskan hingga mencapai suhu tertinggi $\left(110{ }^{\circ} \mathrm{C}\right)$ dan catat hasil pengamatan suhu yang diperoleh.

\section{Identifikasi Komponen Fitokimia 4.1 Uji Tanin}

Masukkan 0,5 g ekstrak etanol 70\% akar dan batang kemangi hutan ke dalam tabung reaksi, tambahkan $10 \mathrm{~mL}$ aquadest, aduk sampai homogen, kemudian saring menggunakan kertas saring. Filtrat yang diperoleh diambil sebanyak $2 \mathrm{~mL}$, tambahkan 2 tetes $\mathrm{FeCl}_{3}$ $1 \%$. Jika terbentuk warna biru atau hijau kehitaman maka ekstrak positif mengandung tanin (Hasibuan dkk., 2020).

\subsection{Uji Flavonoid}

Masukkan 0,5 g ekstrak akar dan batang kemangi hutan dalam tabung reaksi, tambahkan sedikit etanol untuk melarutkan ekstrak, tambahkan pita magnesium dan $\mathrm{HCl} 1 \mathrm{~mL}$. Jika terbentuk larutan warna berwarna kuning, merah, jingga dan hijau menunjukkan adanya flavonoid (Fajriaty dkk., 2018).

\subsection{Uji Saponin}


Masukkan 0,5 g ekstrak akar dan batang kemangi hutan kedalam tabung reaksi, tambahkan $2 \mathrm{~mL}$ etanol $70 \%$ kemudian diaduk, tambahkan $20 \mathrm{~mL}$ aquadest dan dikocok kuat kemudian amati selama 15-20 menit. Jika terbentuk busa maka menunjukan adanya saponin (Sopianti dan Sary, 2018).

\subsection{Uji Alkaloid}

Uji alkaloid di lakukan dengan 2 pereaksi yaitu Mayer dan Wagner :

Masukkan 1 g ekstrak akar dan batang kemangi hutan ke dalam masingmasing tabung $\mathrm{A}$ dan $\mathrm{B}$, tambahkan 2,5 $\mathrm{mL} \mathrm{HCl} 2 \mathrm{~N}$ pada tabung A. Kocok campuran hingga homogen dan dipanaskan. Tambahkan $0,5 \mathrm{~mL}$ reagen Mayer ke dalam tabung A dan 0,5 mL reagen Wagner ke dalam tabung B. Jika pada tabung A terbentuk endapan putih atau kuning dan tabung B terbentuk endapan cokelat maka ekstrak positif mengandung alkaloid (B. Muthmainnah, 2017).

\subsection{Uji Triterpenoid dan steroid}

Masukkan $1 \mathrm{~mL}$ ekstrak akar dan batang kemangi hutan ke dalam tabung reaksi, tambahkan kloroform sebanyak 0,5 mL, dan asam asetat anhidrida sebanyak $0,5 \mathrm{~mL}$, tetesi asam sulfat pekat sebanyak $2 \mathrm{~mL}$ melalui dinding tabung tersebut. Jika terbentuk warna hijau kebiruan menunjukan adanya steroid. Jika terbentuk cincin kecoklatan atau violet menunjukan adanya triterpenoid (Simaremare, 2014).

\section{Analisis Komponen Senyawa Kimia 5.1 KLT (Kromatografo Lapis Tipis)}

Plat KLT dipanaskan dalam oven pada suhu $100^{\circ} \mathrm{C}$ selama 30 menit kemudian didinginkan di udara terbuka selama 1 jam. Potong plat kromatografi lapis tipis (KLT), dengan panjang $5 \mathrm{~cm}$ dan lebar $2 \mathrm{~cm}$, beri garis batas bawah 1 $\mathrm{cm}$ dan batas atas $0,5 \mathrm{~cm}$ dengan pensil.
Masukkan $4 \mathrm{~mL}$ metanol dan $6 \mathrm{~mL}$ aseton ke dalam beaker gelas, campur hingga homogen (digunakan sebagai fase gerak), larutkan ekstrak akar dan batang kemangi hutan sebanyak $0,01 \mathrm{mg}$ dalam tabung reaksi kecil dan tambahkan $5 \mathrm{~mL}$ metanol dalam tabung reaksi tersebut. Campuran ekstrak akar dan batang kemangi hutan ditotolkan pada plat KLT di batas bawah, lalu dikeringkan beberapa menit. Masukkan plat KLT ke dalam botol chamber yang telah berisi fase gerak dan biarkan beberapa menit, sampai ekstrak yang dibawa oleh fase gerak mendekati batas atas pada plat KLT. Plat kromatografi lapis tipis (KLT) diangkat dari botol chamber dan dibiarkan beberapa menit, amati noda hasil pada plat KLT menggunakan lampu UV pada panjang gelombang $254 \mathrm{~nm}$ dan buat lingkaran noda pada plat KLT serta amati warna nodanya. Hitung nilai Rf.

\section{Perlakuan Hewan Uji}

Sebanyak 25 ekor tikus putih yang diberikan pakan standar dan diet lemak tinggi. Kelompok perlakuan dibagi menjadi 5 kelompok yaitu :

Kelompok I :Simvastatin $\quad 0,18$ $\mathrm{mg} / \mathrm{kg} \mathrm{BB}$ tikus.

Kelompok II : Na CMC 0,5\%

Kelompok III : ekstrak akar dan batang kemangi hutan $50 \mathrm{mg} / \mathrm{kg}$ BB tikus.

Kelompok IV : ekstrak akar dan batang kemangi hutan $75 \mathrm{mg} / \mathrm{kg}$ BB tikus.

Kelompok V : ekstrak akar dan batang kemangi hutan 100 $\mathrm{mg} / \mathrm{kg}$ BB tikus.

\section{Pengukuran Kadar Kolesterol dan trigliserida}

Kadar kolesterol dan trigliserida diukur pada hari ke-0, hari ke-20 dan hari ke-34, menggunakan metode CHOD-PAP 
dan GPO-PAP di Rumah Sakit Leona Kupang, menggunakan alat fotometer.

\subsection{Pengukuran Kolesterol Total}

Sebanyak $10 \quad \mu l$ serum ditambah dengan $1000 \mu \mathrm{l}$ reagen kolesterol dan dimasukkan ke dalam tabung reaksi yang sudah disterilisasi, dihomogenkan dan diinkubasi selama 10 menit pada suhu 20$25{ }^{\circ} \mathrm{C}$ dan dibaca absorbansinya dengan alat fotometer (Putri dkk, 2014).

\subsection{Pengukuran Trigliserida}

Sebanyak $10 \mu \mathrm{l}$ serum ditambah dengan $1000 \mu \mathrm{l}$ reagen trigliserida dan dimasukkan ke dalam tabung reaksi yang sudah disterilisasi, dihomogenkan dan diinkubasi selama 10 menit pada suhu 20$25{ }^{\circ} \mathrm{C}$ dan dibaca absorbansinya dengan alat fotometer (Primawestari dan Rustanti, 2014).

\section{Analisis Statistik}

Data penurunan dan peningkatan kadar kolesterol total dan trigliserida yang diperoleh dianalisis menggunakan SSPS, jika data yang diperoleh terdistribusi normal $(\mathrm{P}>0,05)$, maka dilanjutkan dengan pengujian parametrik, tetapi jika diperoleh tidak terdistribusi normal $(\mathrm{P}<0,05)$ maka dilanjutkan dengan uji non parametrik. Pengujian parametrik dilakukan dengan menggunakan ANOVA (Analysis of Variance) yang bertujuan untuk mengetahui perbedaan kontrol dengan perlakuan yaitu One way analisis of variance. Perbedaan dinyatakan dengan nilai $\mathrm{P}<0,05$ sedangkan jika $\mathrm{P}>0,05$ dinyatakan tidak ada perbedaan. Jika ada perbedaan maka dilanjutkan dengan Post Hoc Test yang bertujuan untuk melihat adanya perbedaan diantara masing-masing kelompok perlakuan.

\section{HASIL DAN PEMBAHASAN}

\section{Pembuatan Ekstrak Akar dan Batang Kemangi Hutan}

Hasil ekstraksi $500 \mathrm{~g}$ akar dan $500 \mathrm{~g}$ batang dengan $5000 \mathrm{~mL}$ etanol $70 \%$ mendapatkan ekstrak kental sebesar 18,1 g untuk akar dan 17,68 g untuk batang. Dari berat ini didapatkan nilai rendemen sebesar 3,62\% untuk akar kemangi hutan dan 3,54\% untuk batang kemangi hutan.

Tabel 1. Hasil rendemen ekstrak akar dan batang kemangi hutan

\begin{tabular}{|c|c|c|}
\hline $\begin{array}{c}\text { Berat } \\
\text { serbuk (g) }\end{array}$ & $\begin{array}{c}\text { Berat } \\
\text { ekstrak } \\
\text { kental (g) }\end{array}$ & $\begin{array}{c}\text { Rendemen } \\
\mathbf{( \% )}\end{array}$ \\
\hline 500 (Akar) & 18,1 & 3,62 \\
\hline $\begin{array}{c}500 \\
\text { (Batang) }\end{array}$ & 17,68 & 3,54 \\
\hline
\end{tabular}

Data pada tabel 1 menunjukkan bahwa setiap $1 \mathrm{~g}$ simplisia akar dan batang kemangi hutan menghasilkan 0,0268 g ekstrak akar kemangi hutan dan 0,0191 g ekstrak batang kemangi hutan. Kualitas ekstrak yang dihasilkan biasanya berbanding terbalik dengan jumlah rendemen yang dihasilkan, semakin tinggi nilai rendamen yang dihasilkan maka semakin rendah mutu yang didapatkan (Cahyadi dkk., 2018).

\section{Uji Pelarut Etanol}

Tabel 2. Hasil Uji Pelarut Etanol

\begin{tabular}{|c|l|l|l|}
\hline No & Reagen & Pengamatan & $\begin{array}{c}\text { Simpul } \\
\text { an }\end{array}$ \\
\hline 1. & $\begin{array}{l}\text { Minyak } \\
\text { goreng }+ \\
\text { asam } \\
\text { sulfat } \\
98 \%\end{array}$ & $\begin{array}{l}\text { Tidak tercium } \\
\text { aroma wangi }\end{array}$ & $\begin{array}{l}\text { Alkohol } \\
(-)\end{array}$ \\
\hline 2. & Aquadest & $\begin{array}{l}\text { Angka pada } \\
\text { alkoholmeter } \\
\text { menunjukkan } \\
\text { pada angka 0 }\end{array}$ & $\begin{array}{l}\text { Alkohol } \\
(-)\end{array}$ \\
\hline
\end{tabular}

Hasil uji pelarut dengan cara reaksi esterifikasi didapatkan ekstrak tidak menghasilkan aroma wangi apapun. Sedangkan dengan menggunakan 
alkoholmeter didapatkan alkoholmeter menunjukkan pada angka 0 . Hal ini menunjukkan bahwa kstrak akar dan batang kemangi hutan tidak mengandung alkohol sehingga dapat dikatakan bahwa ekstrak akar dan batang kemangi hutan memiliki mutu yang baik.

\section{Uji Sifat Fisikokimia}

Sifat fisika dan kimia dari suatu molekul atau zat harus diketahui karena sifat ini menentukan kemurnian dari suatu zat yang akan dijadikan obat dan dapat mempengaruhi aktivitas terapetiknya (Sinila, 2016 ; Cartika, 2016).

\section{a. Massa Jenis}

Hasil penetapan massa jenis ekstrak akar dan batang kemangi hutan adalah 0,628 $\mathrm{g} / \mathrm{ml}$. Hal ini menunjukkan bahwa setiap 1 $\mathrm{mL}$ mengandung 0,628 g ekstrak akar dan batang kemangi hutan. Massa jenis kecil menunjukkan $\mathrm{Mr}$ molekul yang dan lebih mudah terabsorbsi sehingga difusi dalam darah cepat dan interaksi dengan reseptor cepat sehingga proses penurunan kolesterol berlangsung lebih cepat. Semakin besar massa jenis maka semakin besar pula $\mathrm{Mr}$ dan struktur senyawa sehingga hambatan sterik makin besar menyebabkan aktivitas biologis menjadi lambat (Beon dan Leki, 2018).

\section{b. Kelarutan}

Tabel 3. Hasil Uji Kelarutan

\begin{tabular}{|c|c|}
\hline Reagen & Simpulan \\
\hline Etanol & Ekstrak larut \\
\hline Aseton $98 \%$ & $\begin{array}{c}\text { Ekstrak sedikit } \\
\text { larut }\end{array}$ \\
\hline $\begin{array}{c}\text { Kloroform } \\
75 \%\end{array}$ & Ekstrak tidak larut \\
\hline Aquadest & Ekstrak larut \\
\hline
\end{tabular}

Hasil uji kelarutan ekstrak akar dan batang kemangi hutan menunjukkan terbentuknya larutan yang homogen pada pelarut polar seperti aquadest dan etanol. Hal ini menunjukkan bahwa ekstrak akar dan batang kemangi hutan banyak membentuk ikatan hidrogen dengan pelarut polar.

\section{c. Titik Didih}

Hasil penentuan titik didih ekstrak akar dan batang kemangi hutan menunjukkan bahwa ekstrak akar dan batang kemangi hutan memiliki titik lebur sebesar $108{ }^{\circ} \mathrm{C}$. Pada suhu $108{ }^{0} \mathrm{C}$ menunjukkan bahwa pada ekstrak akar dan batang kemangi hutan terbentuk banyak ikatan hidrogen antar senyawa sehingga membutuhkan suhu yang tinggi untuk memutuskan ikatan hidrogen tersebut.

\section{Identifikasi Komponen Fitokimia}

Tabel 4. Hasil Identifikasi Kandungan Fitokimia

\begin{tabular}{|c|c|c|c|}
\hline No & $\begin{array}{c}\text { Kelompok } \\
\text { Senyawa } \\
\text { Kimia }\end{array}$ & Reagen & Simpulan \\
\hline 1. & Tanin & $\begin{array}{c}\text { Aquadest + } \\
\mathrm{FeCl}_{3}\end{array}$ & Tanin $(+)$ \\
\hline 2. & Flavonoid & $\begin{array}{c}\text { Pita } \\
\text { magnesium } \\
+\mathrm{HCl} \\
\text { pekat }\end{array}$ & $\begin{array}{l}\text { Flavonoid } \\
\qquad(+)\end{array}$ \\
\hline 3. & Saponin & $\begin{array}{l}\text { Etanol } 70 \% \\
+ \text { aquadest }\end{array}$ & $\begin{array}{c}\text { Saponin } \\
(+)\end{array}$ \\
\hline \multirow[t]{2}{*}{4.} & Alkaloid & $\begin{array}{c}\mathrm{HCl} 2 \mathrm{~N}+ \\
\text { Mayer }\end{array}$ & $\begin{array}{l}\text { Alkaloid } \\
\quad(+)\end{array}$ \\
\hline & Alkaloid & $\begin{array}{c}\mathrm{HCl} 2 \mathrm{~N}+ \\
\text { Wagner }\end{array}$ & $\begin{array}{c}\text { Alkaloid } \\
(+)\end{array}$ \\
\hline \multirow{2}{*}{5.} & $\begin{array}{c}\text { Triterpenoi } \\
\mathrm{d}\end{array}$ & $\begin{array}{c}\text { Kloroform } \\
+ \text { Asam } \\
\text { asetat + } \\
\text { Asam } \\
\text { Sulfat } \\
\text { Pekat }\end{array}$ & $\begin{array}{c}\text { Triterpen } \\
\text { oid }(+)\end{array}$ \\
\hline & Steroid & $\begin{array}{c}\text { Kloroform } \\
+ \text { Asam } \\
\text { asetat + } \\
\text { Asam } \\
\text { Sulfat } \\
\text { Pekat }\end{array}$ & Steroid (-) \\
\hline
\end{tabular}

Hasil identifikasi kandungan fitokimia ekstrak akar dan batang kemangi hutan menunjukkan ada kelompok senyawa tanin, flavanoid, saponin, alkaloid dan triterpenoid. 
5. Analisis Komponen Senyawa Kimia Menggunakan Kromatografi Lapis Tipis (KLT)

Hasil pengamatan dengan menggunakan lampu UV dengan panjang gelombang 254 $\mathrm{nm}$ diketahui terdapat satu noda berwarna kuning coklat dengan nilai $\mathrm{Rf}$ yang didapat adalah 0,82. Hasil analisis menunjukkan bahwa ekstrak akar dan batang kemangi hutan mengandung golongan senyawa alkaloid yang lebih dominan.

6. Pengukuran Kadar Kolesterol Total dan Trigliserida

Pengukuran kadar kolesterol total dan trigliserida dilakukan dengan menggunakan serum darah tikus putih jantan yang diambil pada hari ke 0 sebagai data kadar kolesterol awal/tanpa perlakuan, pada hari ke 20 sebagai data peningkatan kadar kolesterol total dan trigliserida diet lemak tinggi dan pada hari ke 34 sebagai data pengujian aktivitas ekstrak akar dan batang kemangi hutan.

Pengukuran kadar kolesterol total dan trigliserida dilakukan dengan pengambilan darah tikus melalui vena mata dengan tujuan agar darah yang diperoleh lebih banyak jumlahnya, lebih cepat dan lebih steril (Fatimah, 2018). Pengukuran kadar kolesterol total dan trigliserida dilakukan dengan menggunakan metode CHOD-PAP dan GPO-PAP dengan menggunakan alat fotometer.

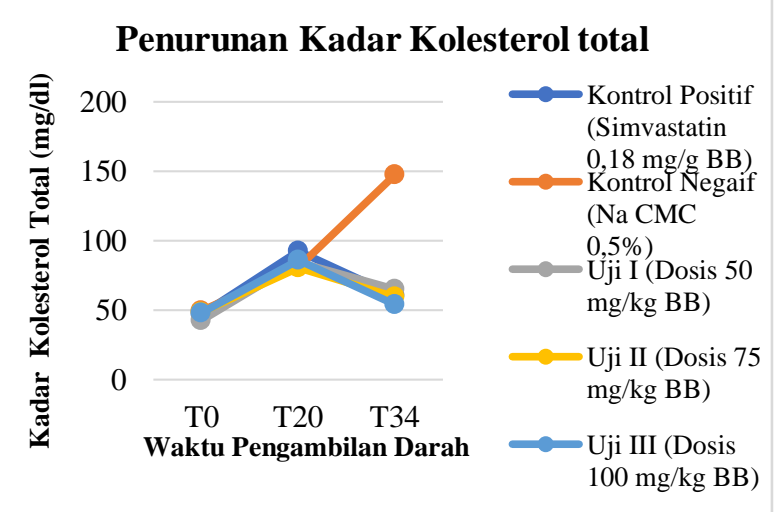

Gambar 1. Grafik penurunan kadar kolesterol total

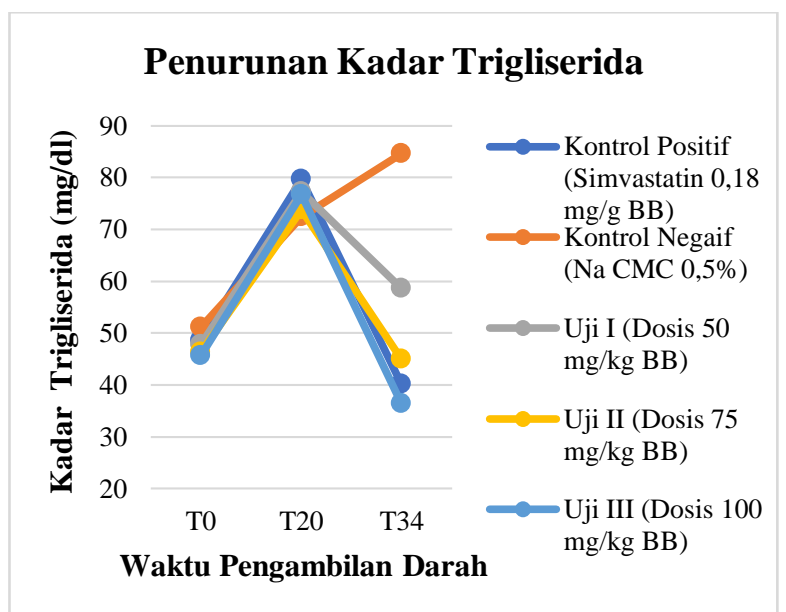

Gambar 2. Grafik penurunan kadar trigliserida

Gambar 1. dan 2. menunjukkan bahwa Dosis III (100 mg/kg BB tikus) memiliki aktivitas yang lebih baik dalam menurunkan kolesterol dibandingkan dengan kontrol positif, dosis II (75 mg/kg BB tikus) dan dosis I (50 mg/kg BB tikus). Hal ini menunjukkan bahwa dosis III (100 mg/kg BB tikus) memiliki lebih banyak gugus aktif yang mampu menurunkan kadar kolesterol. Selisih penurunan kadar kolesterol total untuk dosis I dan kontrol positif tidak berbeda jauh tetapi untuk dosis I dan II memiliki perbedaan yang jauh dengan kontrol positif.

Ekstrak akar dan batang kemangi hutan memiliki aktivitas antihiperkolesterol karena mengandung senyawa aktif seperti eugenol, flavanoid dan tanin. Penurunan kadar kolesterol total dan trigliserida akibat pemberiaan ekstrak akar dan batang kemangi hutan disebabkan karena pada kombinasi ekstrak akar dan batang kemangi hutan memiliki mekanisme kerja yang sinergis dari senyawa aktif kedua bagian tanaman.

Kelompok senyawa flavanoid dapat menurunkan kadar kolesterol dan trigliserida dengan menghambat kerja HMG Ko-A reduktase yang berfungsi untuk mengubah 3hidroksi-3-metilglutaril-Ko-A (HMG Ko-A) menjadi mevalonat dalam sintesis kolesterol di hati. Hambatan ini menyebabkan 
penurunan produksi kolesterol dan meningkatkan jumlah reseptor LDL yang terdapat di dalam membran sel hati dan jaringan ekstrahepatik sehingga kadar kolesterol total akan menurun. Karena terjadinya penurunan kadar kolesterol maka LDL yang berfungsi sebagai alat pengangkut lipid didalam darah akan berkurang kadarnya (Azhari et al., 2017 ; Mutia dkk., 2018)

Senyawa eugenol juga memiliki aktivitas dalam menurunkan kolesterol dengan mekanisme kerja menghambat peroksidasi lipid (Rachmawati dkk., 2019).

Senyawa tanin juga dapat berfungsi dalam menurunkan kolesterol dengan mekanisme kerjanya yaitu dengan membentuk ikatan dengan protein dan melapisi dinding usus halus sehingga penyerapan lemak didalam usus akan terhambat dan terjadinya penurunan sintesis kolesterol (Mutia dkk., 2018).

\section{Analisis Statistik}

Data penurunan kadar kolesterol total selanjutnya dilakukan uji distribusi ShapiroWilk. Uji distribusi Shapiro-Wilk bertujuan untuk melihat apakah data yang diuji terdistribusi normal atau tidak. Hasil uji distribusi Shapiro-Wilk pada kolesterol total dan trigliserida menunjukkan nilai signifikan setiap kelompok perlakuan adalah $\mathrm{P}>0,05$, yang menunjukkan bahwa data yang diperoleh memiliki sebaran yang normal pada setiap kelompok.

Setelah dilakukan uji Shapiro-Wilk dilanjutkan dengan uji homogenitas, uji ini bertujuan sebagai syarat untuk dilakukan uji ANOVA. Hasil uji homogenitas untuk kolesterol total dan trigliserida menunjukkan hasil 0,195 dan $0,812(\mathrm{P}>0,05)$ nilai ini menunjukkan bahwa adanya kesamaan varian dalam satu kelompok perlakuan dan memenuhi syarat untuk dilakukannya uji One Way ANOVA.

Uji One Way ANOVA dilakukan untuk mengetahui apakah ada perbedaan nilai rata- rata antar kelompok perlakuan. Hasil uji One Way ANOVA untuk kolesterol total dan trigliserida menunjukkan nilai 0,00 dan 0,00 $(\mathrm{P}<0,05)$ yang berarti memiliki perbedaan nilai rata-rata antar tiap kelompok.

Selanjutnya dilakukan uji Post hoct dengan teknik Tukey HSD yang bertujuan untuk melihat perbedaan nilai rata-rata antar kelompok uji. Hasil uji Post hoct dengan teknik Tukey HSD menunjukkan bahwa adanya perbedaan yang signifikan dengan kontrol negatif antara kontrol positif, dosis I (50 mg/kg BB tikus), dosis II (75 mg/kg BB tikus) dan dosis III (100 mg/kg BB tikus). Hal ini menunjukkan bahwa kelompok kontrol negatif tidak memberikan aktivitas penurunan kadar kolesterol total dan trigliserida. Sedangkan antara kontrol positif, dosis II (75 mg/kg BB tikus) dan dosis III (100 mg/kg BB tikus) tidak adanya perbedaan yang signifikan, tetapi ada perbedaan signifikan dengan dosis I (50 $\mathrm{mg} / \mathrm{kg}$ BB tikus). Hal ini menunjukkan bahwa dosis III (100 mg/kg BB tikus) dan dosis II (75 mg/kg BB tikus) memiliki aktivitas yang sama dengan kelompok kontrol positif dalam menurunkan kolesterol total dan trigliserida, tetapi kontrol positif dan dosis III (100 mg/kg BB tikus) memiliki aktivitas penurunan kolesterol total dan trigliserida yang berbeda dengan dosis I.

\section{KESIMPULAN}

Berdasarkan hasil penelitian dapat disimpulkan bahwa kombinasi ekstrak akar dan batang kemangi hutan (Ocimum sanctum) memiliki aktivitas antihiperkolesterolemia dengan dosis yang paling baik dalam menurunkan kolesterol total dan trigliserida pada tikus putih yang diberi pakan diet lemak tinggi adalah dosis III yaitu $100 \mathrm{mg} / \mathrm{kg} \mathrm{BB}$ tikus.

\section{DAFTAR PUSTAKA}


Azhari, dkk. 2017. Uji Aktivits Antihiperkolesterolemia Ekstrak Air Buah Belimbing Wuluh (Averrho bilimbi Linn.) Pada Pemodelan Tikus Jantan Galur Wistar Hiperkolesterolemia. Traditional Medicine Journal. 22(1): 61.

Muthmainnah, 2017. Skrining Fitokimia Senyawa Metabolit Sekunder Dari Ekstrak Etanol Buah Delima (Punica granatum L.) Dengan Metode Uji Warna. Media Farmasi. 13(2) ; 26.

Beon dan Leki. 2018. Identifikasi Komponen Fitokimia Dalam Ekstrak Daun Sirih Merah (Piper crocatum). CHMKPharmaceutical Scientific Journal. 1(2): 2-3.

Cahyadi, J., 2018. Skrining Fitokimia Ekstrak Buah Mangrove (Sonneratia alba) Sebagai Bioenrichment Pakan Alami Artemia Salina. Jurnal Borneo Saintek. 1(3): 35 .

Cartika, H., 2016. Kimia Farmasi. Jakarta : Kementrian Kesehatan Republik Indonesia. Hal. 1.

Fajriaty, dkk. 2018. Skrining Fitokimia dan Analisis Kromatografi Lapis Tipis dari Ekstrak Etanol Daun Bintangur (Calophyllum soulatri Burn. F.). Jurnal Pendidikan Informatika dan Sains. 7(1): 57.

Fatimah, Siti dkk. 2018. Total Cholesterol Level of Hypercholesterolemia Male Wistar Rats (Rattus norvegicus) With Ethanol Extracts of Purple Sweet Potato Leaf (Ipomoea batatas (L.) Lam). Journal of Health, 5(1): 37.

Hasibuan, dkk. 2020. Skrining Fitokimia Ekstrak Etanol Umbi Bawang Merah (Allium cepa L). Jurnal farmasi (JFM). 2(2): 46.

Hermin dkk. 2016. Kajian Etnofarmasi Etnik Bungkudi Kecamatan Bungku Tengah Kabupaten Morowaliprovinsi Sulawesi Tengah. Galenika Journal of Pharmacy. 2(2): 77.
Hernawati, dkk. 2013. Perbaikan Parameter Lipid Darah Mnecit Hiperkolesterolemia dengan Suplemen Pangan Bekatul. MKB. 45(1): 2.

Kemenkes RI. 2017. Kemenkes Ingatkan Pola Hidup Cerdik Untuk Hindari Penyakit Jantung.https://www.kemenkes.go.id/artic le/print/17073100005/rs-jantung-harapankita-pengampu-rujukankardiovaskular.html. (diakses 26 Oktober 2019)

Kemenkes RI. 2017. RS Jantung Harapan Kita Pengampu Rujukan Kardiovaskular. https://www.kemenkes.go.id/article/print/ 18111200002/penyakit-jantungpenyebab-kematian-tertinggi-kemenkesingatkan-cerdik-html. (diakses 26 Oktober 2019)

Kementrian Kesehatan Republik Indinesia. 2017. Profil Penyakit Tidak Menular Tahun 2016. Jakarta: Kementrian Kesehatan RI. Hal. 24-25

Kementrian Kesehatan Republik Indonesia. 2018. Laporan Nasional Riskesdas 2018. Jakarta: Kementrian Kesehatan RI. Hal. 150 dan 153.

Lestari Widya dan Utari Diah, 2017. Faktor Dominan Hiperkolesterolemia Pada PraLansia di Wilayah Kerja Puskesmas Rangkapanjaya Kota Depok. Journal of Community Medichine and Public Health. 33(6): 268.

Mutia dkk. 2018. Pengaruh Pemberian Ekstrak Etanol Daun Andong (Cordyline fruticosa (L.) A. Chev) Terhadap Kadar Kolesterol Total dan Trigliserida Darah Tikus Putih (Rattus norvegicus) Hiperkolesterolemia. Urnal Bioleuser. 2(2): 32.

Primawestari, Maria dan Rustanti, Ninik. 2014. Pengaruh Pemberian Susu Koro Pedang (Canavalia ensiformis) Terhadap Kadar Kolesterol Total Dan Trigliserida Serum Tikus Sprague Dawley Hiperkolesterolemia. Journal of Nutrition College. 3(4): 449. 
Putri Yulanda, Yelsa, 2014. Perbedaan Rasio Kolesterol Total/HDL Kelompok Kontrol dan Kelompok Diet Tinggi Minyak Sawit Pada Tikus Wistar. Jurnal Kesehatan Andalas. 3(3): 488.

Rachmawati et al. 2019. Basil Leaves (Ocimum sanctum linn.) Extract Decreases Total Cholesterol Levels in Hypercholesterolemia Sprague Dawley Rats Model. IOP Conf. Series: Materials Science and Engineering. 546.

Samak, Geetha et al. 2007. Hypolipidemic Efficacy Of Ocimum Sanctum In The Prevention Of Atherogenesis In Male Albino Rabbits. Pharmacology online. 2: 124.

Sinila, S. 2016. Farmasi Fisik. Jakarta : Kementrian Kesehatan Republik Indonesia. Hal. 3.

Simaremare, Eva. 2014. Skrining Fitokimia Ekstrak Etanol Daun Gatal (Laportea decumana (Roxb.) Wedd). Pharmacy 11(1):101, 102.

Sopianti dan Sary. 2018. Skrining Fitokimia dan Profil KLT Metabolit Sekunder Dari Daun Ruku-Ruku (Ocimum tenuiflorum L.) dan Daun Kemangi (Ocimum sanctum L.). SCIENTIA Jurnal Farmasi dan Kesehatan, 8(1): 46.

Susiwati. 2018. Analisis Kolesterol Low Density Lipoprotein (Ldl) Pada Pengkonsumsi Produk Minuman Herbal "X" Kota Bengkulu Tahun 2017. Journal of Nursing and Public Health, 6(2): 96.

Tjay TH, Rahardja K. 2015. Obat-Obat Penting (Khasiat, Penggunaan dan Efek-efek Sampingnya). Jakarta: Penertbit Elex Media Komputindo. Hal. 571, 572, 573, 577, 578, 583

Yani, Muhhamad. 2015. Mengendalikan Kadar Kolesterol Pada Hiperkoles-terolemia. Jurnal Olahraga Prestasi, 11(2): 2. 